\title{
Learning by Doing in Mathematics Class of Fisheries Agribusiness Student in Agriculture Polytechnics Kupang
}

\author{
Sri Imelda Edo ${ }^{1, *}$, Wahyuni Fanggi Tasik ${ }^{2}$, Yusuf Kamlasi ${ }^{3}$ \\ ${ }^{1}$ Politeknik Pertanian Negeri Kupang, Kupang city, East Nusa Tenggara- Indonesia \\ ${ }^{2}$ Politeknik Pertanian Negeri Kupang, Kupang city, East Nusa Tenggara-Indonesia \\ ${ }^{3}$ Politeknik Pertanian Negeri Kupang, Kupang city, East Nusa Tenggara-Indonesia \\ *Corresponding author. Email: sriimeldaedo@gmail.com
}

\begin{abstract}
Mathematics is an important subject for understanding almost every subject whether science and technology, medicine, the economy, or business and finance. Previous research shows that many agricultural students have deficient mathematical skills for their future profession after their education. They also indicated that there is often a weak link between mathematics teaching in vocational education and the labour market. Fisheries agribusiness students did not really seem to understand the importance of learning mathematics and they claimed that learning mathematics means doing with formula, memorize algorithm, calculate and manipulate without understanding. While several researchers found that students working with an integrated mathematics education have more motivation, they learn better, and understand and remember more, when it's related to their reality. Therefore, this research aimed to see the effect of learning by doing in mathematics for students' achievement and motivation. All of 47 first semester students in fisheries agribusiness study program participate in this research. Pretest-posttest experiment compiles with survey research was chosen as the research methods to reach the goal. Paired sample t-test showed Asymp. Sig. (2-tailed) $=0,057(\mathrm{p}>0.05)$ means that learning mathematics by doing can improve students achievement. Moreover, $75 \%$ students have high motivation, $20 \%$ average motivation and $5 \%$ have low motivation.
\end{abstract}

Keywords: Learning by doing in mathematics, mathematics learning for vocational education, mathematics for agribusiness class. Teaching Mathematics.

\section{INTRODUCTION}

Mathematics is an important subject and knowledge of it enhances a person's reasoning, problem-solving skills, and in general, the ability to think. Hence it is important for understanding almost every subject whether science and technology, medicine, the economy, or business and finance. Statistics and probability which are branches of mathematics are used in everyday business and economics. Previous research stated that many agricultural students have deficient mathematical skills for their future profession after their education. They also indicated that there is often a weak link between mathematics teaching in vocational education and the labor market. Consequently, the students may have problems when they enter the labor market, because their mathematical knowledge is not sufficient for the requirements that they encounter there.

Moreover, Muhrman (2015) indicate that mathematical skills are essential for a professional farmer, but according to those interviewed, many agricultural students have deficient mathematical skills for their future profession after their education. Many of the farmers also said they do not want to hire someone who doesn't have sufficient skills of mathematics since miscalculations can mean costly mistakes. The farmers claimed that they did not need any advanced skills but that they must have very 
good basic mathematical knowledge, since there is often advanced applications of the mathematics.

In fact, Fisheries agribusiness students in agriculture Polytechnics Kupang did not really seem to understand the importance of learning mathematics and they claimed that learning mathematics means doing with formula, memorize algorithm, calculate and manipulate without understanding. Whereas, several researchers found that students working with an integrated mathematics education have more motivation, they learn better, and understand and remember more, when it's related to their reality. Edo and Tasik (2019) Said that learning trajectory on applied realistic mathematics education (RME) approach in teaching math for vocational college can improve students' understanding. Students enjoy the learning process and give a very enthusiastic response.

Siong and Thow (2017) stated that "learning-bydoing" engage students in direct experiences that are tied to real world situations, and to develop students' interpersonal skills. The adoption of the "learning-bydoing" approach to teach Digital Electronics to the first-year students has been a successful effort. The surveys and interviews conducted with the students affirm the effectiveness of this approach in enhancing the students' motivation in learning Digital Electronics, as compared to those students who learn Digital Electronics in the traditional way. "learningby-doing" approach which allows students to build their understanding of concepts through a process of inquiry and reflection. IN addition, Member of professional learning communities DuFour, et.al, (2013) recognize that learning by doing develop a deeper and more profound knowledge and greater commitment than learning by reading, listening, planning or thinking.

Therefore, this research aimed to see the effect of learning by doing in mathematics to improve students' achievement and motivation. The key objective of adopting this "learning-by-doing" approach in teaching first-year fisheries agribusiness students on Mathematics is to motivate them and increase their interest this course.

\section{THEORY}

Learning by doing means learning from experiences resulting directly from one's own actions, as contrasted with learning from watching others perform, reading others' instructions or descriptions, or listening to others' instructions or lectures. Of course, watching, reading, and listening are actions, but they are not the kinds of doing referred to as learning by doing because they yield direct experience with demonstrations or descriptions of actions rather than with actions the learner actually performs (Reese, 2011).

The rationale for learning by doing in this research were activities based on the idea that deep learning occurs when students are encouraged to engage in productive learning activities (de Jong, 2005; Kirschner, Sweller, \& Clark, 2006; Klahr \& Nigam, 2004; Lillard, 2005; Mayer, 2003, 2004). Involve students in case study about fishing. They were facilitated to observed fisherman activities, fishing gear, and fish distribution. They also have the chance to interview fisherman and distributor about the amount of fish they catch and distribute each month of each species. In which season the amount of fish tend to increase and decrease. What kind of fishing and distribution obstacle, How fisherman handle the problem. Furthermore, students presents data in line, bar, and pie charts. Constructing line, bar, and pie charts can be considered a productive learning activity because the learner must engage in an activity that is related to the instructional objective selecting relevant data of each species of fish and organizing them into a coherent table and choose appropriate charts.

\section{METHOD}

To achieve the purpose of the study a mixed method design was carried out. For the quantitative part a pre-post test design was carried out. Data analysis techniques for measure students' motivation were descriptive quantitative studies. This study involved 47 students in Fisheries agribusiness study program of agriculture polytechnics Kupang, East Nusa Tenggara-Indonesia conducted within 4 weeks. There were $44.68 \%$ of female student and $55.32 \%$ of male student.

In the beginning, students were given the explanation about the benefit of mathematics for their field. Teaching and learning process used learning by doing approach, means that learning mathematics by doing or practice to solve the problem related to students' major. Then, they were given teaching material and practice guide. After that, students were asked to collect data from fisherman and fish distributor used questionnaire provided by lecturer. After got the data, they were given 8 eight test item to tabulate data, present data on bar diagram, pie diagram, and line chart. Then they asked to interpret or describe the data from bar diagram, pie diagram, and line chart. Students paper test were corrected as 
pretest achievement, after that, students facilitated by teacher to learn mathematics by doing in order to explore and construct students understanding and skill about the concept of line, bar, and pie diagram, present data in various diagram manually on Plano paper, and use Microsoft excel, and interpret the data. These activities conducted within 4 weeks.

Furthermore, Learning motivation measurement based on aspects of learning motivation that developed by Keller (1987) consisting of attention, (relevance), confidence, and satisfaction or also known as ARCS. The Instructional Materials Motivation Survey (IMMS) was developed by Keller as a data collection tool to examine students motivation in learning mathematics by doing. The IMMS measures student motivation towards specific instructional materials. The IMMS originally consists of 36-item survey with a Liker type scale (Keller, 2010) and has four categories (Attention, Relevance, Confidence, and Satisfaction). The response scale ranges from 1 (Not True) to 5 (Very True).

Data analysis techniques for measure students' achievement as the effect of learning by doing treatment were used paired sample t test to answer the hypothesis whether the means of students achievement on pretest and posttest have significance difference or not. Students were given pre conceptual understanding with the same concept before study was conducted as a pretest. After revealing some materials, they were given post-test conceptual understanding and achievement to find Mean difference between pretest and posttest.

Data analysis techniques for measure students' motivation were descriptive quantitative studies. Scoring of Students motivation level based on likert scale. The motivation of studying mathematics is grouped into three categories, namely height, moderate, and low. Data analysis techniques for know the motivation category of studying mathematics through the questionnaire is carried out by accumulating scores from all respondent.

\section{RESULT}

This research used eight test items as an instrument to collect data in order to answers research question. The items' reliability, validity, and index of difficulties had been analyzed before conducted the research. Test items consist of two easy questions, four moderate questions and two difficult questions. The index of item difficulties present on table 1 .
Table 1. Index difficulty of test Items

\begin{tabular}{|c|c|c|}
\hline $\begin{array}{c}\text { Number } \\
\text { of items }\end{array}$ & $\begin{array}{c}\text { Index of } \\
\text { difficulty }\end{array}$ & Category \\
\hline 1 & 0.4539 & Moderate \\
\hline 2 & 0.8227 & Easy \\
\hline 3 & 0.695 & Moderate \\
\hline 4 & 0.5745 & Moderate \\
\hline 5 & 0.298 & Difficult \\
\hline 6 & 0.163 & Difficult \\
\hline 7 & 0.667 & Moderate \\
\hline 8 & 0.759 & Easy \\
\hline
\end{tabular}

Test items have Cronbach's alpha reliability 0.634 , it means that test items have strong correlation or a measure has good test reliability and internal consistency. Meanwhile, the validity of each test items presented on table 2 .

Table 2. The test item validity

\begin{tabular}{|c|c|c|}
\hline $\begin{array}{c}\text { Number } \\
\text { of items }\end{array}$ & $\begin{array}{c}\text { Pearson } \\
\text { Correlation }\end{array}$ & Sig. (2-Tailed) \\
\hline 1 & $.501^{* *}$ & .000 \\
\hline 2 & $.501^{\star *}$ & .000 \\
\hline 3 & $.514^{* *}$ & .000 \\
\hline 4 & $.493^{* *}$ & .000 \\
\hline 5 & $.522^{* *}$ & .000 \\
\hline 6 & $.454^{* *}$ & .001 \\
\hline 7 & $.643^{* *}$ & .000 \\
\hline 8 & $.611^{* *}$ & .000 \\
\hline
\end{tabular}

Table 2 showed that all of items have Sig. (2tailed $)=0,000$ and $0,001(p<0,005)$. It means that all items were valid.

Normality of data were analyze as a prerequisite analysis of paired sample $t$ test. The result showed Asymp. Sig. (2-tailed) =0,057 ( $p>0.05)$, It means that the data was distributed normally. Therefore, prerequisite analysis has been met, and students 
fulfill the prerequisite as the dependent sample to answer the research question.

In the beginning, students were divided into five groups, and each group was asked to interviewed

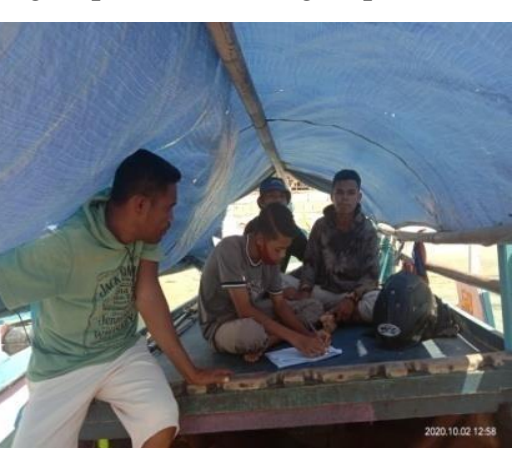

fisherman in five difference seaport spread in Kupang city, East Nusa Tenggara Indonesia. Those seaports are Lasiana, Oesapa, Kelapa Lima, Oeba, and Pasir panjang. Students' activities in interview fisherman and fish distributor, showed on figure 1.
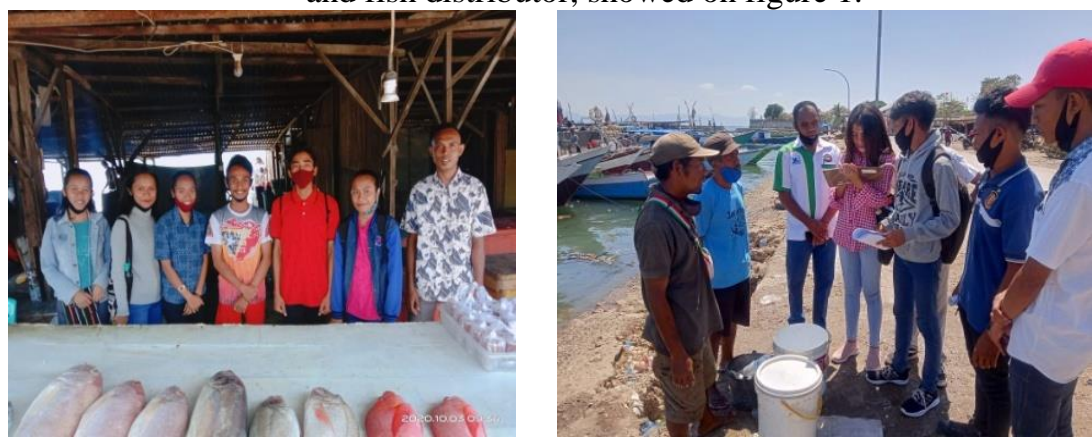

Figure 1. Student were interviewing fishermen in 5 different fish port

They collected data about the species of fish targeted by fishermen; the species of fish targeted depend on their unit tools. How many fish of each species they caught in every month. What factor that affected their catching increase or decrease. How many Gear they have, where they sell the fish, and what species of fish have the good seller. This paper concerned about how can students tabulate the raw data and presented it into suitable chart or diagram. They as agribusiness students have to skillful in present and interpret data. The data collected by group 3 about the number of fishing In Lasiana Port as shown in figure 2.

\begin{tabular}{|c|c|c|c|c|c|c|c|c|c|c|c|c|c|}
\hline \multirow{3}{*}{\begin{tabular}{c} 
Nama Nelayan \\
\cline { 2 - 15 }
\end{tabular}} & & 1 & 2 & 3 & 4 & 5 & 6 & 7 & 8 & 9 & 10 & 11 & 12 \\
\hline $\begin{array}{c}\text { 1. pak } \\
\text { Muslimin }\end{array}$ & Tembang & 100 & 150 & 150 & 200 & 250 & 300 & 400 & 750 & 850 & 1000 & 650 & 450 \\
\cline { 2 - 14 } & Tongkol & 100 & 150 & 150 & 200 & 400 & 600 & 800 & 1500 & 1600 & 2000 & 950 & 450 \\
\cline { 2 - 13 } & Ikan Kue & 80 & 100 & 150 & 150 & 200 & 300 & 300 & 550 & 700 & 950 & 650 & 300 \\
\hline
\end{tabular}

Figure 2. The Raw Data collected by students in Lasiana seaport

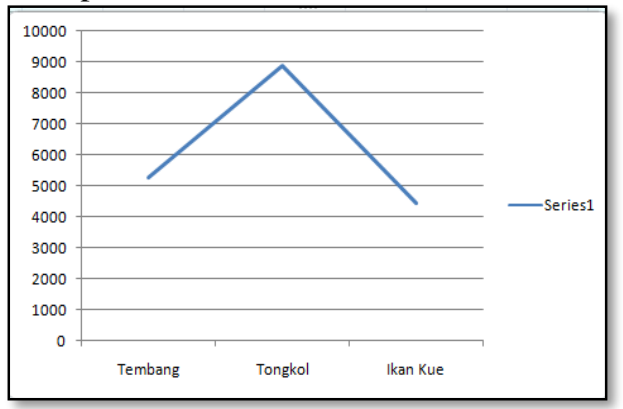

A
Figure 2 showed that there are three species of fish targeted by Mr. Muslimin, namely ikan tembang (sardine), Ikan tongkol (tuna fish), and ikan kuwe (Pompano).

Based on the data, students were challenged to tabulate data from raw data to be processed data, and then present it into various types of charts. One of the task gave to students was they were asked to present the data about the number fishing of three fish species during one year from January to December simultaneously on one diagram. Then interpret the diagram to explain when the number of fishing increase, stagnant, and decrease, by compared their continuity.

Following figure showed an example answer of a student to show the process of how fisheries agribusiness students doing in mathematics class.

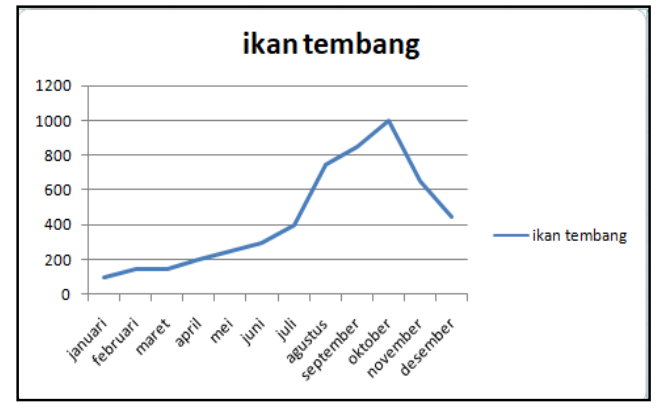

B 


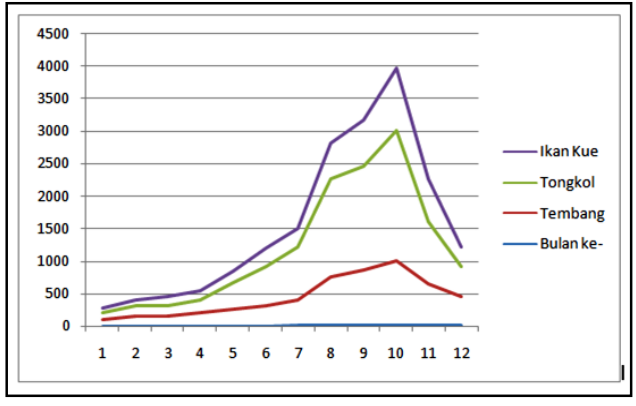

C

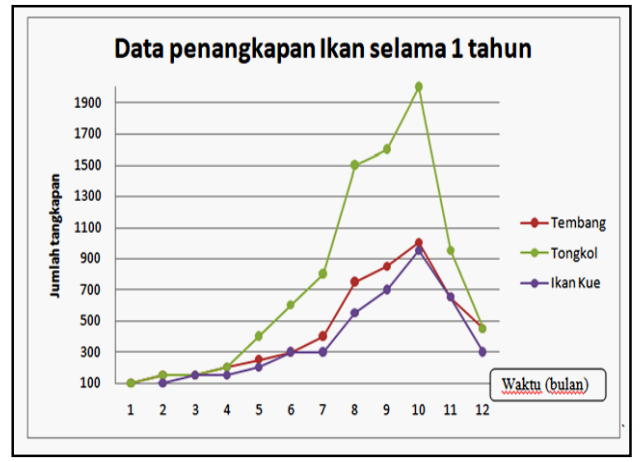

$\mathrm{E}$

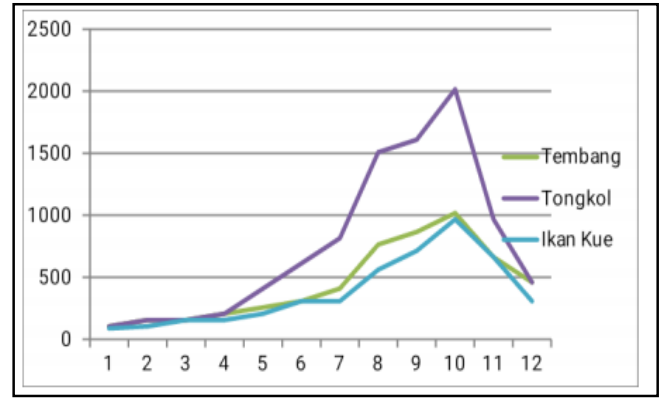

D

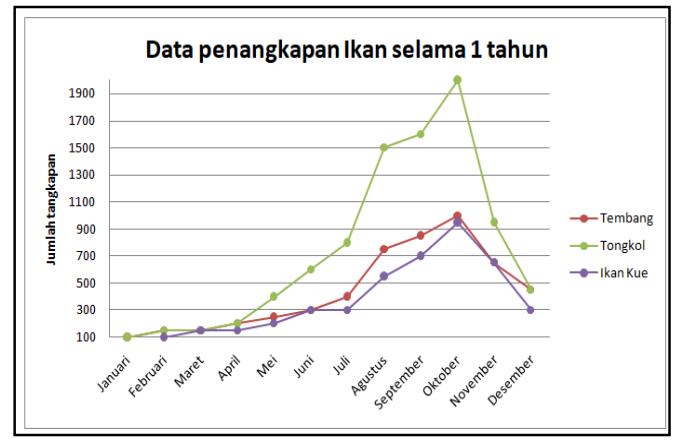

F

Figure 3. Six trials student made in presenting the number of fishing into line chart.

Figure 3a showed that student was concerned to show the number fishing of three fish species. Therefore, she counted total number fishing of each fish species per year, then she insert line chart. But she cannot interpreted the result well, in order to answer the questions. The chart did not give the continuity of fishing per month over one year. Then she changed the data tabulation which tabulated the number fishing of each species per month. For example, the number of tembang fishing per month. Then, she inserted line chart showed in figure $3 \mathrm{~b}$. Although her answer was better than before, it cannot answer the question which asked her to present the data of three species simultaneously in one diagram. So, the lecture asked her to be fighting, revised and try again until he got suitable chart. Figure $3 \mathrm{c}$ showed that student was tabulated the data correctly, but she found difficulty in present it into Table 3. Paired sample t test analysis line chart. The figure $3 \mathrm{c}$ has four lines to present the number of Tembang, tongkol, kuwe, and the month. Therefore, it has to revise. The next revise showed by figure $3 \mathrm{~d}$ which student presented the data correctly. Otherwise, the lecture asked her to format several feature of chart, such as format axis value and data series to make the figure more precise and commutative. The fifth revised showed by figure $3 \mathrm{e}$. Her answer was surprised the lecture because she add text in the horizontal axis to explained that the horizontal axis label was about the time in month. Lecturer asked her to edit axis label range. Her final revised showed by figure $3 \mathrm{f}$.

For seeing the difference between pretest and posttest after applied learning by doing in mathematics, paired t-test was conducted. The results of analysis presented in table 3 .

\begin{tabular}{|c|c|c|c|c|c|c|c|}
\hline \multirow[t]{2}{*}{ Mean } & \multirow{2}{*}{$\begin{array}{l}\text { Standard } \\
\text { deviation }\end{array}$} & \multirow{2}{*}{$\begin{array}{l}\text { Std. Error } \\
\text { mean }\end{array}$} & \multicolumn{2}{|c|}{$95 \%$ confidence Interval } & \multirow[t]{2}{*}{ T } & \multirow[t]{2}{*}{ df } & \multirow[t]{2}{*}{ Sig. (2-tailed) } \\
\hline & & & Lower & Upper & & & \\
\hline$-1.09167 \mathrm{E} 1$ & 7.86274 & 1.13489 & -13.19977 & -8.63356 & -9.619 & 47 & .000 \\
\hline
\end{tabular}

Table 3 reported that there were significant differences of pretest and post test with $\mathrm{t}=-9,619$ and sig. $=0.000(\mathrm{p}<0.05)$. This showed the hypothesis $(\mathrm{Ho})$ that there was no significant difference of students' achievement before and after the used learning by doing in mathematics was rejected, and we accept $\mathrm{H} 1$ that there was a significant difference of students' achievement before and after the used learning by doing in mathematics. Therefore, it could be concluded that students' achievement before and after the used learning by doing in mathematics in fisheries agribusiness study program, agriculture polytechnics Kupang, East Nusa Tenggara-Indonesia was significantly different. 
Furthermore, Student motivation mean was 81.91 . There are $75 \%$ of students have high motivation, $20 \%$ of students have moderate motivation, and $5 \%$ of students have low motivation in learn mathematics by doing. The percentage of each learning motivation aspects are Attention (80. 86\%), Relevance (75.08\%), Confidence $(70.28 \%)$, and Satisfaction $(78.14 \%)$. The applied of learning by doing just not improve students cognitive aspects but also affective and motor aspect

\section{DISCUSSION}

The analysis showed that students' score in posttest was higher than pretest. Worksheet based on learning by doing integrated with ARCS motivation was the main factor enhancing conceptual understanding student. Students can identify the types of data which appropriate to present on bar, pie and line diagram. They look present and interpret data fluency and very enthusiastic. The finding supported by DuFour, et.al, (2013) stating that learning by doing develop a deeper and more profound knowledge and greater commitment than learning by reading, listening, planning or thinking. Learning by doing means learning from experiences resulting directly from one's own actions. Doing referred to as learning by doing because they yield direct experience with demonstrations or descriptions of actions.

Learning by doing supported students' motivation in each learning motivation aspect attention, relevance, confidence, and satisfaction. The adoption of the "learning-by-doing" approach to teach first-year students of fisheries Agribusiness study program agriculture polytechnics Kupang has been a successful effort. The surveys and interviews conducted with the students affirm the effectiveness of this approach in enhancing the students' motivation in learning mathematics. This fact supported by Siong, (2017) stated that learning by doing approach effective to improve students' motivation and increase their interest in learning. However, the sample size of this study was limited by the small size of fisheries Agribusiness students.

\section{CONCLUSION}

Paired sample $\mathrm{t}$ test showed that $\mathrm{t}=-9,619$ and sig. $=$ 0.000 ( $\mathrm{p}<0.05)$. This means that we rejected Initial hypothesis (Ho) and accepted alternative hypothesis (H1). It was means that there was significant difference of students' achievement before and after the used learning by doing in mathematics. Therefore, it could be concluded that the used learning mathematics by doing can improve students' achievement in fisheries agribusiness study program, agriculture polytechnics Kupang, East Nusa Tenggara-Indonesia.
Furthermore, $75 \%$ of students in fisheries agribusiness study program, agriculture polytechnics Kupang, East Nusa Tenggara-Indonesia have high motivation in learning mathematics means that application of learning by effective to motivate them in learning mathematics. Students with moderate and low motivation category were caused by the lack of students' interest in learning Mathematics. Meanwhile, The percentage of each learning motivation aspects are Attention (80.86\%), Relevance (75.08\%), Confidence $(70.28 \%)$, and Satisfaction $(78.14 \%)$. The applied of learning by doing just not improve students cognitive aspects but also affective and motor aspect. Thus learning by doing is one of powerful learning, especially for polytechnics students.

\section{ACKNOWLEDGMENTS}

The researchers would like to express gratitude to the Polytechnics of Agriculture Kupang (Politeknik Pertanian Negeri Kupang), for funding this research and providing the opportunity and facility to conduct this study.

\section{REFERENCES}

[1] Kim and J. M. Keller, "Motivation, volition and belief change strategies to improve mathematics learning," Journal of Computer Assisted Learning, vol. 26, no. 5, pp. 407-420, Aug. 2010, doi: 10.1111/j.1365-2729.2010.00356.x.

[2] D. K. Meyer, J. C. Turner, and C. A. Spencer, "Challenge in a Mathematics Classroom: Students' Motivation and Strategies in Project-Based Learning," The Elementary School Journal, vol. 97, no. 5, pp. 501-521, May 1997, doi: $10.1086 / 461878$.

[3] G. E. Siong and V. S. Thow, "THE EFFECT OF USING 'LEARNING-BY-DOING' APPROACH ON STUDENTS' MOTIVATION IN LEARNING DIGITAL ELECTRONICS," in Proceedings of the 13th International CDIO Conference, Calgary, Canada, Jun. 2017, pp. 18-22.

[4] H. W. Reese, "The learning-by-doing principle.," Behavioral Development Bulletin, vol. 17, no. 1, pp. 1-19, 2011, doi: 10.1037/h0100597.: Performance Evaluation (SFM), Springer, Berlin, Heidelberg, 2007, pp. 220-270. DOI:

[5] J. M. Keller, "Development and use of the ARCS model of instructional design," Journal of Instructional Development, vol. 10, no. 3, pp. 210, Sep. 1987, doi: 10.1007/bf02905780.

[6] K. Muhrman, "Mathematics in agriculture and vocational education for agricultures," in Proceedings of the Ninth Congress of the European 
Society for Research in Mathematics Education (CERME9), Feb. 2015, pp. 1669-1670, [Online]. Available: https://hal.archives-ouvertes.fr/hal01287937.

[7] M. Blanco Abellán, M. Ginovart Gisbert, M. R. Estela Carbonell, and E. Jarauta Bragulat, "Teaching and learning mathematics and statistics at an agricultural engineering school," Quaderni di Ricerca in Didattica/Mathematics (QRDM), vol. 19, no. 3, pp. 43-49, 2009, Accessed: Apr. 10, 2021. [Online]. Available: http://hdl.handle.net/2117/8951.

[8] N. V. Vargas, J. L. A. Ortiz, V. M. A. Ceballo, "Project Based Learning in the Technical and Vocational Education and Training" INTERNATIONAL JOURNAL OF ENVIRONMENTAL \& SCIENCE EDUCATION, vol. 13, no. 9, pp. 767-776, Nov. 2018.

[9] S. I. Edo and W. F. Tasik, "Design research on applied Realistic Mathematics Education (RME) approach in teaching math for vocational college," Jurnal Pendidikan Vokasi, vol. 9, no. 3, pp. 294306, Dec. 2019, doi: 10.21831/jpv.v9i3.27839.

[10] T. V. Pham and C. R. Jimenez, "An accurate paired sample test for count data," Bioinformatics, vol. 28, no. 18, pp. i596-i602, Sep. 2012, doi: 10.1093/bioinformatics/bts394. 